Offshoring innovation: An empirical investigation of dyadic complementarity within SMEs

Khraishi, A., Huq, F., Paulraj, A.

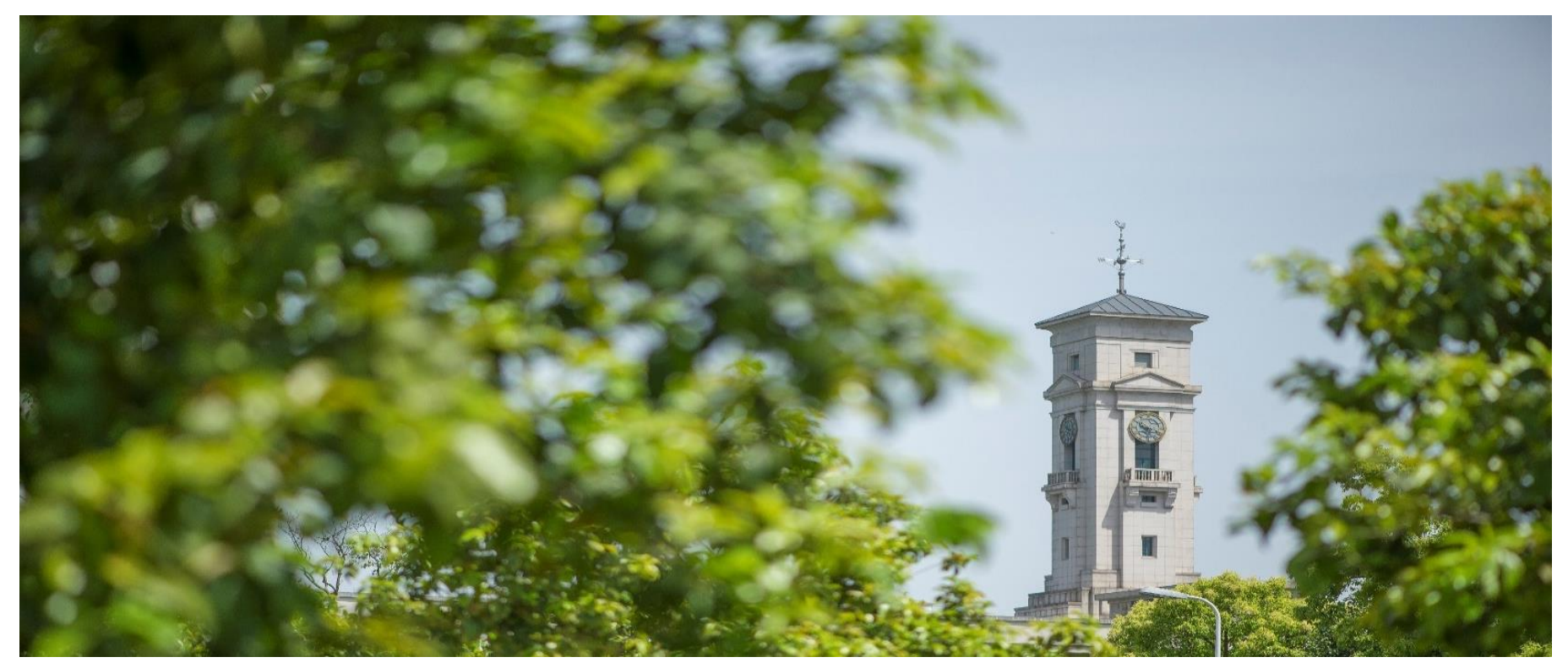


Faculty of Business, University of Nottingham Ningbo China, 199 Taikang East Road, Ningbo, 315100, Zhejiang, China.

First published 2020

This work is made available under the terms of the Creative Commons Attribution 4.0 International License:

http://creativecommons.org/licenses/by/4.0

The work is licenced to the University of Nottingham Ningbo China under the Global University Publication Licence:

https://www.nottingham.edu.cn/en/library/documents/researchsupport/global-university-publications-licence-2.0.pdf 


\title{
Offshoring innovation: An empirical investigation of dyadic complementarity within SMEs
}

\author{
Ahmad Khraishi \\ Alliance Manchester Business School \\ The University of Manchester \\ Booth Street W, \\ Manchester M15 6PB \\ Phone: + 44(0)7586232001 \\ Email: Ahmad.Khraishi@manchester.ac.uk \\ Fahian Huq \\ Alliance Manchester Business School \\ The University of Manchester \\ Booth Street W \\ Manchester M15 6PB \\ Phone: +44(0)1612756484 \\ Email: Fahian.Huq@manchester.ac.uk \\ Antony Paulraj \\ Nottingham University Business School China \\ Room 248 Trent Building \\ University of Nottingham Ningbo \\ 199 Taikang East Road, Ningbo 315100, China \\ Phone: +86 (0) 57488180000 - 8631 \\ Email: Antony.Paulraj@nottingham.edu.cn
}




\begin{abstract}
Despite scholarly agreement that complementary capabilities are essential to successful collaborations, little is known about how small and medium-sized enterprises (SMEs) manage collaborative innovation through offshoring. Besides, the innovation management literature remains generally silent about when supplier joint actions could work in enhancing offshoring innovation (OI) performance. The purpose of this study is twofold. First, we aim to delineate why supplier's asset specificity and goal compatibility predict supplier's complimentary capabilities in OI. Second, we empirically explore the role of supplier joint actions in enhancing OI performance. Based on data collected from 200 SMEs having active OI relationships spanning four developed European countries, our results propose that supplier's complementary capabilities mediate the relationship between critical relational antecedents (supplier's asset specificity and goal compatibility) and OI performance. It should be noted, however, that despite their incentivising power, supplier joint actions can be a "double-edged sword" in SMEs' OI relationships.
\end{abstract}

\title{
1. Introduction
}

Despite extensive research and general scholarly agreement that complementary capabilities are essential to successful offshoring innovation collaborations (Cobena, Gallego, \& Casanueva, 2017; Jap, 1999; Mindruta, Moeen, \& Agarwal, 2016; Mitsuhashi \& Greve, 2009; Nietoa \& Santamaria, 2007; Rothaermel \& Boeker, 2008; Van Beers \& Zand, 2014), the role of suppliers' complementary capabilities remains underexplored in the case of offshoring innovation (OI) in SMEs (Gusenbauer, Massini, \& Fink, 2015; Musteen \& Ahsan, 2013). We envision OI as the act of transferring to the offshore supplier any element of the innovation process, including collaborative research and development (R\&D), supplier involvement in new product development (NPD) and the commercialisation of innovations (Gusenbauer et al., 2015; Quinn, 2000). For example, consider the significant impact on new product and process 
innovations in manufacturing industries due to the rapid advancement in electronics and software technologies (Nietoa \& Santamaria, 2007; Quinn, 2000). Moreover, the continuous rise in OI relationships since early 2000s has proven that OI allows buying firms to access and benefit from offshore suppliers and country-specific resources, such as specialised talents, technological advances, and lower innovation costs than in developed countries (Lewin, Massani, \& Peeters, 2009; Spithoven \& Teirlinck, 2015; Van Beers \& Zand, 2014). OI in SMEs is consistent with the relational view (Dyer \& Singh, 1998) which purports SMEs to engage in OI strategies to substitute for in-house deficiencies in innovation resources and capabilities (Lewin et al., 2009; Spithoven \& Teirlinck, 2015; Teece, 1986).

As a dyadic construct, complementary capabilities imply that distinctive capabilities of alliance partners are complementary in that their joint performance generates a value that is greater than each one by itself (Dyer \& Singh, 1998; Enderwick \& Buckley, 2017; Gulati, Lavie, \& Singh, 2009; Jap, 1999; Lavie, 2006; Sarkar, Echambadi, Cavusgil, \& Aulakh, 2001; Sivadas \& Dwyer, 2000). For SMEs, OI provides access to skills and resources that reside with the offshore supplier but are strategically essential for the SMEs survival and growth (Dussauge, Garrette, \& Mitchell, 2000; Sarkar et al., 2001). Therefore, given the SMEs' limited internal resources, supplier's complementary capabilities can act as a shift parameter from a "make" to a "buy" innovation strategy (De Vita, Tekaya, \& Wang, 2010; Spithoven \& Teirlinck, 2015). However, to access the synergetic benefits of OI, SMEs should possess organisational capabilities to appropriate relational rents from leveraging the supplier's complementary capabilities (Dyer \& Singh, 1998). For example, to manage OI relationships, SMEs would need to allocate valuable management resources to coordinate OI projects across their national borders (Gusenbauer et al., 2015). Moreover, SMEs should recruit qualified boundary spanners to interact with the offshore suppliers, and develop long-term interfirm relationships (Munjal, Requejo, \& Kundu, 2018; van de Vrande, de Jong, Vanhaverbeke, \& de 
Rochemont, 2009). Accordingly, SMEs must learn how to compensate for their resource disadvantage by increasing the scope and level of interaction with the offshore suppliers (Munjal et al., 2018; van de Vrande et al., 2009).

Notwithstanding these arguments, it is accepted that SMEs are not simply small versions of large firms (Gusenbauer et al., 2015). Consequently, SMEs' distinctive size and managerial characteristics (e.g. resources disadvantages, entrepreneurial mindset, etc.) may influence their OI decisions and paths (Gusenbauer et al., 2015; Laforet, 2008; Lee, Park, Yoon, \& Park, 2010). For example, previous studies argued that SMEs engage in offshoring innovation strategies to substitute for in-house deficiency in innovation resources, while large firms mainly offshore innovation to complement their innovation activities (Lewin et al., 2009; von Haartman \& Bengtsson, 2015). Furthermore, innovation studies have shown that although SMEs have higher innovative productivity than large firms in terms of idea generation, they often lack adequate resources for the commercialisation of innovations, which in turn, motivates their OI behaviour (Lee et al., 2010). Besides, SMEs use their relatively flat and flexible structure in motivating fast OI decisions (Gusenbauer et al., 2015; Marcati, Guidoa, \& Peluso, 2008). These specific characteristics of SMEs could mean that they are more likely to benefit from OI than large firms due to resource shortcomings and higher propensity to explore new ideas (Lee et al., 2010; Musteen \& Ahsan, 2013; Mykhaylenko, Motika, Waehrens, \& Slepniov, 2015). However, the same characteristics can hinder successful selection of suitable supplier for OI and limit the SMEs' control over the OI performance (Gusenbauer et al., 2015; Quinn, 2000; Quinn \& Hilmer, 1994). In light of these specific characteristics of SMEs, the present study aims to investigate the role that supplier's asset specificity and goal compatibility play in allowing SMEs to exploit supplier's complementary capabilities in OI relationships.

Additionally, SMEs are usually a weak representation of the focal firm in dyadic and network alliances (Albors-Garrigos, Etxebarria, Hervas-Oliver, \& Epelde, 2011; Julien, 1993). 
Compared to large firms, SMEs often have access to a smaller pool of small or less specialised suppliers to choose from (Koufteros, Vickery, \& Dorge, 2012; Mindruta et al., 2016). Also, SMEs have limited capacity concerning the number of OI relationships they can afford to establish and maintain (Mitsuhashi \& Greve, 2009). Thus, aside from their limited choices and chances of finding the right offshore suppliers and locations for their OI endeavour, SMEs must also learn to master the art of collaborative innovation with offshore suppliers (Gusenbauer et al., 2015; Mitsuhashi \& Greve, 2009).

The OI literature have recognised supplier's asset specificity and goal compatibility as two relationship specific factors that explain the role of supplier's complementary capabilities in generating relational rents from OI relationships (Chiang, Kocabasoglu-Hillmer, \& Suresh, 2012; Jap, 1999; Joshi \& Stump, 1999; Mudambi \& Tallman, 2010; Rothaermel \& Boeker, 2008; Stump \& Heide, 1996; Wang, Li, \& Chang, 2016). However, little empirical research has shown the links between supplier's asset specificity and partners' goal compatibility and the SMEs' ability to leverage supplier's complementary capabilities as a source of relational rent in OI relationships (Gusenbauer et al., 2015). Against this backdrop, in this study we aim to delineate: (1) why the supplier's asset specificity and goal compatibility predict the supplier's complementary capabilities, and (2) how the supplier's complementary capabilities might affect the performance of OI in SMEs.

Considerable supply chain literature suggested that rewarding suppliers by experimenting with them jointly (Villenaa, Revillaa, \& Thomas Y. Choi, 2011); and training their teams during site visits (Modi \& Mabert, 2007), help in motivating their cooperative behaviour and creativity (Villenaa et al., 2011). Other studies suggested that supplier incentives can be a “double-edged sword” in OI relationships (Gilliland \& Kim, 2014). Despite these contrasting studies, the innovation management literature has given limited attention to the interplay between supplier joint actions and antecedents of dyadic performance, such as the supplier's 
asset specificity and goal compatibility (Johnson \& Medcof, 2007; Shepherd \& DeTienne, 2005; Stump \& Heide, 1996). Moreover, studies of buyer-supplier collaboration remain generally silent about the effectiveness of supplier joint actions in enhancing supplier performance (Gilliland \& Kim, 2014). The purpose of this study is to address these gaps.

Our study intends to contribute to the SMEs and the OI research and practice by conceptualising and examining OI in SMEs from the theoretical perspective of the relational view (Dyer \& Singh, 1998). An important contribution of this study is the identification of supplier's asset specificity and goal compatibility as essential antecedents of supplier's complementarity in SMEs' OI relationships. Our empirical investigation provides evidence to support the theory that the supplier's contributions through relationship-specific assets and OI partners' goal compatibility are contingencies under which supplier's complementary capabilities improve OI performance. Additionally, we reveal that despite their incentivising nature, supplier joint actions can have negative effects on tapping interfirm synergies in SMEs' OI relationships.

\section{Theory and hypotheses}

\subsection{Offshoring innovation in SMEs: The buyer-supplier alliance perspective}

Extant literature has documented that OI is not a recent phenomenon; instead, it goes back to 1930s when large American and European firms relocated some of their R\&D activities abroad (Ambos \& Ambos, 2011). Moreover, captive offshoring innovation dominated the early years of OI (Lewin et al., 2009). However, Hagedoorn (2002) showed that since early 1980s companies seem to increasingly prefer contractual partnerships for innovation over joint ventures. Consequently, the strong trend toward OI has been gaining momentum since the early 2000s (Bertrand \& Mol, 2013; Lewin et al., 2009; Musteen \& Ahsan, 2013). OI is driven by firms' attempts to tap into the offshore suppliers' technological resources and the foreign markets for specialised talents (Lewin et al., 2009; Quinn, 2000). Also, firms are increasingly realising that OI can be a faster, cost-effective and low risk way to innovation and sustained 
competitive advantage (Gusenbauer et al., 2015; Jean, Sinkovics, \& Hiebaum, 2014; Quinn, 2000; Sartor \& Beamish, 2014).

Previous studies have also documented a growing shift in SMEs' innovation strategies towards adopting OI practices through buyer-supplier relationships (Gassmann, Enkel, \& Chesbrough, 2010; Lewin et al., 2009; Musteen \& Ahsan, 2013; Rothwell \& Dodgson, 1991). For example, Di Gregorio, Musteen, and Thomas (2009) concluded that offshoring technical services are enhancing SMEs' international competitiveness through opportunities to tap into talent pools of foreign suppliers. Musteen and Ahsan (2013) found that through OI, SMEs overcome human, social and organizational capital deficiencies and improve their innovation performance. Another study by Rodriguez and Nieto (2016) concluded that Offshoring R\&D stimulates higher sales growth for SMEs than domestic R\&D outsourcing. .

OI is one variant of buyer-supplier relationships with a distinct emphasis on the transfer of part or all internal innovation tasks to an offshore supplier (Gusenbauer et al., 2015; Spithoven \& Teirlinck, 2015). Moreover, OI relationships with offshore suppliers enable buyer SMEs to reduce risks of innovations, enhance product quality, and increase new products' speed to market (Nietoa \& Santamaria, 2007; Whitley \& Willcocks, 2011). However, OI is distinct from traditional offshoring of non-core activities (e.g. offshoring production). First, there is a higher level of loss of control since it involves sharing of specific tacit knowledge (Frishammar, Ericsson, \& Patel, 2015; Hoecht \& Trott, 2006). Second, firms pursuing innovation through offshoring must develop inter-organisational capabilities to integrate suppliers' tacit knowledge and valuable resources (Enderwick \& Buckley, 2017; Gooroochurn \& Hanley, 2007; Mudambi \& Tallman, 2010). On the contrary, in typical offshoring of noncore tasks, the emphasis is on disintegration, and cost savings. Third, OI requires the development of interdependent relationships through strategic collaboration, while the offshoring of non-core tasks focuses on labour distribution (I. J. Chen \& Paulraj, 2004; 
Rothaermel \& Boeker, 2008). To that end, OI requires substantial coordination efforts to facilitate the achievement of desired innovation outcomes (Jap, 1999; Nietoa \& Santamaria, 2007; Palmie et al., 2016).

The strategic alliance research, argues that firms pursuing innovation through offshore outsourcing are usually motivated by survivability and profitability considerations that are stronger than transaction cost economics (TCE) (Dussauge et al., 2000; Gooroochurn \& Hanley, 2007; Teece, 1986). Specifically, firms adopting OI as a "buy" innovation strategy, lose the advantages of organisational control of the "make" innovation strategies (Stanko \& Calantone, 2011; Teece, 1986); consequently, OI shifts the organisation behaviour and coordination mechanisms of innovation from the firm to the dyad (I. J. Chen \& Paulraj, 2004). This conceptualisation of OI comprises various joint activities in a coordinated effort to create superior value for buyers. Therefore in conceptualising OI, we follow the perspective of the relational view (Dyer \& Singh, 1998). The central thesis of the relational view asserts that firms in dyadic alliances can accumulate relational rents by accessing and combining each other's complementary idiosyncratic capabilities (Dyer \& Singh, 1998). Therefore, OI, by definition, fosters joint innovation through bundling the offshore suppliers' specialised resources and tacit knowledge with the buyers' complementary internal resources (Enderwick \& Buckley, 2017; Spithoven \& Teirlinck, 2015). OI allows the buyer SMEs to benefit from utilising heterogeneous and immobile resources of the offshore suppliers under the dyad's relaxed conditions of resource proprietary and imperfect mobility (Lavie, 2006; Van Beers \& Zand, 2014).

\subsection{Supplier's complementary capabilities}

In this study, we refer to the supplier's complementary capabilities as the degree to which the SME buyer and the offshore supplier can combine the supplier's distinct capabilities to jointly produce performance outcomes that are not achievable by either of the two acting individually 
(Dyer \& Singh, 1998; Lavie, 2006; Sarkar et al., 2001). Consequently, supplier's complementary capability can be a source of relational value for SME buyers in OI relationships (Dyer and Singh 1998). For the purpose of our study, resources and capabilities are interchangeable. However, we deliberately highlight capabilities to incorporate a dynamic perspective in our analysis of OI relationships. A dynamic view seems more appropriate to understand how supplier's complementary capabilities combine not only supplier's distinctive attributes but also the SME-offshore supplier interactions to co-create super-additive value in OI (Mudambi \& Tallman, 2010; Nietoa \& Santamaria, 2007). Besides, given their limited resources, SMEs are required to integrate the technological advances of their suppliers into their products (Fernández-Olmos \& Ramírez-Alesón, 2017). Therefore, when SMEs fail to generate strategic competitive advantage because of their limited capabilities, supplier's complementary capabilities facilitate complex interfirm combination of the offshore supplier superior capabilities with the SMEs' weaker capabilities (Cobena et al., 2017; Mitsuhashi \& Greve, 2009; Rothaermel \& Boeker, 2008; von Haartman \& Bengtsson, 2015).

While the strategic interfirm literature documents that supplier's complementary capabilities can be a source of OI viability and success, SMEs in dyadic OI relationships must be aware of the challenges they might face while pursuing relational gains from adding up supplier's complementary capabilities (Dyer \& Singh, 1998; Jap, 1999; Lavie, 2006; Sivadas \& Dwyer, 2000). First, the SMEs must assess the potential complementarity of the offshore supplier before they make the supplier selection decision (Dyer \& Singh, 1998). Second, the SMEs must build inter-organisational skills to permit the appropriation of synergetic value when accessing the supplier's complementary capabilities (Lavie, 2006; Sivadas \& Dwyer, 2000). These challenges are substantial in the case of SMEs due to their limited experience in foreign markets, imperfect resources to invest in search and evaluation of potential offshore 
suppliers, and their weaker position compared to large firms in global supply chain networks (Pawar, Huq, Khraishi, \& Shah, 2018).

In the following subsections, we explain the reasons why the supplier's asset specificity and goal compatibility enhance supplier's complementary capabilities, and how the supplier's complementary capabilities then affect the performance of OI for SMEs. Further, we develop our proposed model of supplier's complementary capabilities in SMEs' OI relationships (Figure 1).

[Insert Figure 1 about here]

\subsubsection{Supplier's asset specificity and supplier's complementary capabilities.}

Supplier's asset specificity refers to the investments made to match the buyer's specific requirements at the actual site, or in physical and human capabilities (e.g. installation of new design software, or updating of existing production equipment with the latest technology) (Joshi \& Stump, 1999). Such investments can be a viable route to enhance supplier's complementary capabilities and lead to competitive interfirm performance (Dyer \& Singh, 1998; Lavie, 2006). Specifically, supplier's asset specificity overcomes shortages in buyers' resources by offering distinct capabilities (Teece, 1986). Previous studies document that supplier's asset specificity fosters partners' interdependence and hence cultivate dyadic complementarities (Dussauge et al., 2000; Dyer, 1996; Rothaermel \& Boeker, 2008). For example, Dyer (1996) concluded that suppliers' specific investments in the auto industry are more likely to result in competitive advantage for automakers, particularly when tasks involved are characterised by a high degree of interdependence, such as collaborative innovation (Dyer, 1996). Similarly, Rothaermel and Boeker (2008) found that specialised niches of biotechnology firms often lead to complementary effects when combined with pharmaceutical firms' competences in administrative management, marketing, and distribution activities. 
Supplier's asset specificity also entails assets' heterogeneity and immobility which are primary conditions for complementarity (Cobena et al., 2017; Dyer \& Singh, 1998; Lavie, 2006). For example in the context of OI, Mudambi and Tallman (2010) argued that decisions of offshoring knowledge tasks are usually encouraged by accessing specialised suppliers' capabilities in offshore markets and combining them with outsourcers own capabilities. Furthermore, offshore suppliers often deploy specific investments because of their role as the international provider in the OI buyer-supplier relationships (Anderson \& Jap, 2005; Stump \& Heide, 1996). However, relationship-specific assets expose offshore suppliers to the risk of buyers' opportunism. Therefore, offshore suppliers might shirk their future investments unless their buyers are willing to swap mutual hostages in return (Anderson \& Jap, 2005; Poppo, Zhou, \& Zenger, 2008; Stump \& Heide, 1996).

In case of SMEs, where OI is primarily motivated by shortages in internal resources, finding heterogeneous offshore suppliers who are willing to invest in new assets is highly relevant to achieving complementarity (Mitsuhashi \& Greve, 2009). Also, the supplier's asset specificity signals the offshore supplier's commitment to intentionally invest in the relationship , and mobilise specialised capabilities for the alliance's benefit (Lavie, 2006). Finally, supplier's asset specificity prompts supplier's complementary capabilities to play the role of an effective governance mechanism in international buyer-supplier relationships over and above the usual contractual agreements (Bunyaratavej, Hahn, \& Doh, 2007). Such a role facilitates a cooperative climate where the SME expects that the offshore supplier will share its specialised assets to enhance OI performance (Koufteros et al., 2012). Likewise, the offshore supplier expects his share of the benefit (e.g. promises of future orders) gained from the operationalised dyadic complementarity (Joshi \& Stump, 1999; Koufteros et al., 2012; Mitsuhashi \& Greve, 2009). Applying this rationale to supplier's asset specificity in SMEs' OI relationships, we propose the following hypothesis: 
Hypothesis (H1). Supplier's asset specificity is positively related to the supplier's complementary capabilities in SMEs' OI relationships.

\subsubsection{Goal compatibility and supplier's complementary capabilities.}

Goal compatibility refers to the extent to which the goals and objectives of the SME buyer are aligned with the goals and objectives of the offshore supplier (Werder, 2005). For example, goal compatibility in OI buyer-supplier relationships can be perceived as the possibility of accomplishment of joint innovation creation (Jap, 1999; Sarkar et al., 2001). Additionally, goal compatibility in OI can be a shared vision that represents collective goals of partners (Wang et al., 2016). Dyer and Singh (1998) argue that finding a supplier with complementary capabilities creates a potential for relational rents. However, such rents can be realised only if both parties have compatible goals that motivate them to consolidate supplier's complementary capabilities. For example, Wang et al. (2016) studied 323 dyadic new product co-development (NPD) relationships in China and found that the more compatible the goals of the parties in these relationships, the more able were they to achieve complementary interfirm rents. According to Wang et al. (2016)'s study, compatible goals help partners to recognise their interdependence in NPD projects and consequently facilitate effective cooperation to achieve collaborative outcomes.

Also, from an organisation's internal perspective, innovation teams are usually goal driven (Stanko \& Calantone, 2011). For example, internal R\&D teams typically have a common goal, and all individuals within that team behave in line with this goal (Forsgren, 2002). Therefore, the innovation process emerges as a purposeful, adaptive and constructive process, resulting from the interaction between outcomes and goals (Poole \& Van de Ven, 1995). The same contention can apply at the inter-organisational level, where interconnected organisations can act as a single collective entity to achieve desired outcomes if they have compatible goals (Poole \& Van de Ven, 1995). On the other hand, since SMEs might not be 
able to develop the supplier's complementary capabilities internally, goal compatibility is an attractive mechanism that ensures tapping potential rents of the offshore suppliers' complementary capabilities (Lavie, 2006). Moreover, SME entrepreneurs make good use of goal compatibility as a motivational tool to form interdependencies, engender flexibility, and drive both parties' contributions (Julien, 1993; Mitsuhashi \& Greve, 2009; Rothaermel \& Boeker, 2008). Contrarily, goal incompatibility between partners can impair collaboration, since it frustrates partners who become suspicious of each other's opportunistic behaviour (Jap, 1999; Wang et al., 2016). Therefore, the strategic alliance research suggests that partners with competing goals should not enter into dyadic relationships, as such relationships are doomed to fail (Dyer \& Singh, 1998; Jap, 1999). Following this discussion, we hypothesise that:

Hypothesis (H2). Goal compatibility is positively related to the supplier's complementary capabilities in SMEs' OI relationships.

\subsubsection{Supplier's complementary capabilities and OI performance.}

The alliance literature established that relational rents are high in alliances between partners possessing complementary capabilities (Dyer \& Singh, 1998; Lavie, 2006; Sivadas \& Dwyer, 2000). Previous OI studies have shown that the supplier's complementary capabilities is a relational antecedent of OI performance, and a primary driver of OI decision (Nietoa \& Santamaria, 2007; Rothaermel \& Boeker, 2008). Moreover, recent studies noted that supplier's complementary capabilities in dyadic alliances predict alliance formation and success (Cobena et al., 2017; Mindruta et al., 2016; Van Beers \& Zand, 2014).

In OI, supplier's complementary capabilities arise when the combination of different types of technological knowledge, $R \& D$ processes, or innovation commercialization capabilities of both partners lead to enhanced product and process innovations of the buyer's firm (Cobena et al., 2017; Mitsuhashi \& Greve, 2009; Van Beers \& Zand, 2014). For example, offshore suppliers can provide technological knowledge for production process innovations of 
SMEs (Van Beers \& Zand, 2014). Also, offshore suppliers might be members of specialised clusters with access to creative workforce (Lewin et al., 2009). Furthermore, SMEs can leverage offshore suppliers' core strengths in $\mathrm{R} \& \mathrm{D}$, engineering and production technologies in areas where they have deficiencies (Nietoa \& Santamaria, 2007; Rothaermel \& Boeker, 2008; Van Beers \& Zand, 2014). Accordingly, supplier's complementary capabilities may foster new learning opportunities for SMEs through collaboration with offshore suppliers who have a broader knowledge base about new technologies and markets than SMEs (Koufteros et al., 2012; Nietoa \& Santamaria, 2007; Van Beers \& Zand, 2014). Summing up, the supplier's complementary capabilities facilitate a feasible OI route for SMEs to achieve a superior innovation performance at the competitive cost in offshore markets (Cobena et al., 2017; Mitsuhashi \& Greve, 2009; Rothaermel \& Boeker, 2008). Therefore, we hypothesise:

Hypothesis (H3). The supplier's complementary capabilities are positively related to SMEs' OI performance.

\subsubsection{The mediation role of the supplier's complementary capabilities.}

So far, we argued that the supplier's asset specificity and the partners' goal compatibility nurture supplier's complementary capabilities, which, in turn, become critical determinants of potential relational rents for SMEs in OI relationships. These arguments mean that supplier's complementary capabilities may also play a mediatory role in the relationship between relational antecedents and performance of OI relationships (Cobena et al., 2017; Mitsuhashi \& Greve, 2009). The strategic alliance and supply chain literatures established that interfirm diversity due to idiosyncratic investments as well as social and cultural similarities affects the alliance performance (Dyer, 1996; Jap, 1999; Jean, Kim, \& Bello, 2017; Sarkar et al., 2001). Both factors can reinforce the importance of supplier's complementary capabilities. For instance, supplier's asset specificity is an efficient way for a supplier to signal to the buyer its attractiveness as a potential collaborative partner, and, in doing so, the supplier is better 
positioned to explain the potential value of its own complementary capabilities (Nietoa \& Santamaria, 2007; Rothaermel \& Boeker, 2008; Van Beers \& Zand, 2014). Also, partners' collective goals as well as shared vision to achieve joint innovation outcomes can further foster a conducive climate of interfirm complementarity (Wang et al., 2016). Further, supplier's asset specificity and goal compatibility are envisioned to act as valid proxies for supplier's complementary capabilities (Cobena et al., 2017; Jap, 1999; Mitsuhashi \& Greve, 2009; Sarkar et al., 2001).

Also, supplier's complementary capabilities can serve as an effective medium to transmit the economic effects of supplier's asset specificity and the social bonding effect of goal compatibility to OI performance (Cobena et al., 2017; Mitsuhashi \& Greve, 2009). In summary, supplier's complementary capabilities create added value through the combination of the offshore supplier idiosyncratic capabilities and the buyer-supplier interactions. Specifically, SMEs benefit from this mediatory role of supplier's complementary capabilities in accruing relational rent from suppliers' capabilities which the SMEs do not own or control (Enderwick \& Buckley, 2017; Mudambi \& Tallman, 2010). Furthermore, given distant offshore relations, SMEs can utilise supplier's asset specificity and goal compatibility as relatively less expensive control mechanisms than, for example, face to face meetings. Therefore, we hypothesise:

Hypothesis (H4a). The supplier's complementary capabilities will mediate the positive relationship between the supplier's asset specificity and OI performance.

Hypothesis (H4b). The supplier's complementary capabilities will mediate the positive relationship between goal compatibility and OI performance.

\subsection{The Moderating effects of supplier joint actions.}

Although supplier's asset specificity and goal compatibility in OI relationships are critical drivers of performance and success, they are potentially significant sources of risks (Flynn, 
Hou, \& Zhao, 2010; Jap, 1999; Joshi \& Stump, 1999; Mudambi \& Tallman, 2010; Nyaga, Whipple, \& Lynch, 2010; Rothaermel \& Boeker, 2008; Wang et al., 2016). For example, suppliers who invested heavily in relationship-specific assets are subject to substantial lock-in risks in case of buyers switching to other suppliers (Liu, Huang, Luo, \& Zhao, 2012). Moreover, compatible goals often suffer from multiple and conflicting interpretations in interfirm relationships across borders and among different teams and organisations (L. H. Chen, Ellis, \& Suresh, 2016; Gilliland \& Kim, 2014; Kim, Choi, \& Skilton, 2015).

Previous studies have proposed that supplier joint actions aimed at supplier development are critical drivers of collaborative success (Flynn et al., 2010; Huq, Stevenson, \& Zorzini, 2014; Nyaga et al., 2010). These include working with the supplier to reduce costs, improve quality, and train personnel. Supplier joint actions can act as effective incentives to focus the supplier's efforts on the mutual benefits of superior exchange performance (Heide \& John, 1990; Joshi \& Stump, 1999). In addition, supplier joint actions not only encourage cooperative behaviour through "working together" to resolve disputes and coordinate collaborative activities (Nyaga et al., 2010), but also act as a non-contractual control mechanism to deter opportunism (Joshi \& Stump, 1999; Liu et al., 2012; Nyaga et al., 2010).

Despite their limited financial resources to engage in vast and expensive supplier development programs like the ones Toyota implements with their suppliers (Lawson, Krause, \& Potter, 2015), SMEs can still benefit from the incentivising nature of low scale supplier joint actions to ensure the supplier's dedicated efforts and contributions towards enhancing the OI performance (Lui, Ghauri, \& Sinkovics, 2010; Mooi \& Ghosh, 2010). For example, SMEs can help the offshore supplier to improve the utilisation and productivity of its specific assets through the use of information and communication technology (ICT)'s electronic linkages to exchange information with the offshore supplier instead of prolonged site visits (Zhang, Dirk Pieter Van Donk, \& van der Vaart, 2016). Consequently such inexpensive supplier joint actions 
can unleash for SMEs relational benefits from supplier's specific asset (Johnson \& Medcof, 2007; Nyaga et al., 2010; Shepherd \& DeTienne, 2005; Sumo, van der Valk, van Weele, \& Bode, 2016). This means that supplier joint actions enable SMEs to tap better into supplier's asset specificity. In contrast, in the absence of such incentivising activities, suppliers are likely to fear the SMEs' opportunistic behaviour and consequently provide less than expected performance (Mooi \& Ghosh, 2010).

Similarly, as supplier joint actions in OI become increasingly oriented towards securing economic gains for the offshore supplier, such interactions will positively moderate the impact of compatible goals on OI performance (Lui et al., 2010). For example, working jointly with the supplier's innovation team during joint training programs, and frequent technical meetings though ICT linkages, will facilitate the offshore supplier alignment with the OI objectives and consequently enhances the effect of goal compatibility on OI performance (Jane, Kim, \& Sinkovics, 2012; Kulangara, Jackson, \& Prater, 2016; Zhang et al., 2016). Besides, through supplier joint actions, parties in OI relationships value shared goals and hence can derive higher relational rents (Liu et al., 2012). Consequently, through supplier joint action, SMEs increase the possibility of benefiting from goal compatibility in drawing better OI performance. In contrast, the lack of supplier joint actions will challenge the quality of shared social capital in OI relationships and hinder the chances of the continuation and success of the OI relationship (Jean et al., 2017; Lui et al., 2010). This discussion suggests the study's final two hypotheses: Hypothesis (H5a). Supplier joint actions positively moderate the relationship between the supplier's asset specificity and OI performance.

Hypothesis (H5a). Supplier joint actions positively moderate the relationship between goal compatibility and OI performance.

\section{Methodology}




\subsection{Sampling and data collection}

This study is part of a broader research that investigates OI relationships in SMEs, drawing from a data set of 200 developed country European SME manufacturers with active OI relationships. We specifically choose OI in a buyer-supplier context. Offshore outsourcing relationships has been researched extensively as forms of fruitful interfirm cooperation (Bunyaratavej et al., 2007; Maskell, Pedersen, Petersen, \& Dick - Nielsen, 2007). Accordingly, they offer an excellent opportunity to draw useful insights for research and practice in case of pursuing innovation through offshore outsourcing. Moreover, buyer-supplier or non-equity OI relationships can be more attractive to SMEs than captive relationships given their limited resources (Rodriguez \& Nieto, 2016). Furthermore, previous studies argued that non-equity offshoring relationships adapt better than equity arrangements (Buvik \& John, 2000) as they assist buyers to share with suppliers risks of innovations (Hamel, Doz, \& Prahalad, 1989), and move quickly into new markets and technologies (Quinn, 2000).

According to the European economic data, the SMEs manufacturing sector in Europe included more than 2 million firms and produced $€ 725$ billion or $44.5 \%$ of the manufacturing sector value added in 2013 (Eurostat, 2016). Furthermore, in 2014, SMEs contributed 26.3\% to the manufacturing sector value added in Germany, and from $10.5-14.5 \%$ in Italy, UK and France (Eurostat, 2017). Additionally, the European innovation data reported that $49.1 \%$ of all European SMEs had reported some form of innovation activity between 2012 and 2014 (Eurostat, 2017). For data collection, we used an online cross-sectional survey in line with previous studies with similar context (e.g. van de Vrande et al. (2009). Our initial sampling frame included 2,384 firms. The survey targeted manufacturing SMEs from four developed European countries; Germany, Italy, UK and France with an existing OI relationship with a supplier located in a country different than the country of the SME (Bunyaratavej et al., 2007; 
Geishecker \& Görg, 2013; Maskell et al., 2007). More than 50\% of the supplier firms in our sample were in a different continent than Europe.

We screened out a total of 1,466 firms from the initial sample since they did not meet the SME size criteria or the study criteria for a buyer-supplier OI governance mode. The final sample size was 918 firms. All the SMEs in our sample fulfilled the EU definition of SMEs i.e. each has a total number of employees between 10-249 and an annual turnover of more than $€ 2$ to $€ 50$ million (European Commission, 2016). We excluded SMEs with captive OI since the primary goal of the research is to investigate OI in a buyer-supplier context. Moreover, the buyer-supplier context is more relevant to SMEs given their resource constraints, and their high-risk exposure of foreign direct investments (FDIs) compared to large firms (Gusenbauer et al., 2015; Rodriguez \& Nieto, 2016).

To ensure complete responses, we activated the forced response option for all questions. Also, to encourage high-quality responses, we added an attention check midway through the survey to make sure that respondents are paying adequate attention. Further, we screened out all responses with a completion time less than $1 / 3$ of the median time of all completed responses. After screening out incomplete responses and responses that failed quality checks, the final sample contained 200 firms, giving us an effective response rate of $21.8 \%$. We surveyed top managers of SMEs. Key informants, especially in case of SMEs, are typically in charge of establishing and managing strategic relationships, given the small management structure in SMEs and the challenges of managing OI relationships (Bidault \& Castello, 2010; Gusenbauer et al., 2015).

Furthermore, surveying top executives (e.g. chief executive officer, managing partner) from the buyer side are a commonly adopted practice in supply chain and operations management research (Carr \& Pearson, 1999; Paulraj, Lado, \& Chen, 2008). Our sample came 
Offshoring Innovation in SMEs

from various manufacturing industries. The industry type of the 200 SME in the data set and respondent titles are listed in Table 1.

[Insert Table 1 about here]

\subsection{Survey development and measures}

Since our unit of analysis is the offshoring SME with existing OI relationship, we instructed the respondents to select a significant offshore supplier with whom they have an active OI relationship. Such a mindset helped us to increase the validity of respondents' views about their offshore suppliers. We developed our survey instrument using multiple item measures from published research. The study's survey used a 7-point Likert scale with endpoints "1= strongly disagree" and "7= strongly agree". Before the commencement of the live data collection, we contacted eight manufacturing executives from SMEs spanning Italy, UK, Germany, and Spain, and asked them to complete the survey. We contacted them again to request their feedback about the questions in the survey, with respect to clarity, length, and coverage for the OI investigated topics. The final questionnaire included some modifications based on the comments we received from the manufacturing executives of the SMEs.

To measure "supplier's asset specificity" we used four items from Joshi and Stump (1999). The items measured the extent to which the offshored innovation tasks needed highly specified human and physical resources. Additionally, this construct also captured the extent to which the offshore supplier has made dedicated and specialised investments for the OI relationship, has tailored its product and process development programs to match the SME buyer requirements, and has committed specialized skills in training the SME buyer people. To measure "goal compatibility", we used three items from Jap (1999) and Wang et al. (2016). The items measured the extent to which the SME and the offshore supplier have compatible goals, support each other's objectives, and share the same goals in the relationship. To measure “supplier's complementary capabilities" we applied four items which assess the extent to which 
the offshore supplier contributes different capabilities to the OI relationship, has complementary strengths. In addition to the degree to which the offshore supplier has separate abilities when combined with the SME's abilities enable the SME to achieve goals beyond its reach independently, and whether the joint $R \& D$ efforts benefit from their closeness to both firms' current products and processes (Jap, 1999; Sivadas \& Dwyer, 2000). To measure "supplier joint actions" we used a three-item scale to assess the extent to which the offshoring SME is working with the offshore supplier to reduce its costs, improve its quality, and train its people (Joshi \& Stump, 1999). Finally, we operationalised OI performance using a four-item scale, measuring OI performance concerning new or enhanced products and processes, new product speed to market, and rate of patent applications (Jane et al., 2012; Rindfleisch \& Moorman, 2001; Roy \& Sivakumar, 2011).

\subsection{Data analysis}

3.3.1. Common method bias. Since we collected data from a single informant within each SME in our sample, common method variance is of concern. To address this concern, we conducted two tests. First, we conducted the Harman's one-factor test (Podsakoff, MacKenzie, Lee, \& Podsakoff, 2003). According to this test, if a substantial amount of common method variance is present, then either (1) a single factor will emerge from the exploratory factor analysis (EFA) of all survey items, or (2) one general factor will account for most of the variance in the data set. In our case, the un-rotated principal component EFA based on Eigenvalue greater than one, revealed the presence of four distinct factors with Eigenvalue greater than one. The four factors together accounted for $64.36 \%$ of the variance. Further, the first factor accounted for $39.41 \%$ of the variance. Second, we ran a single factor confirmatory factor analysis (CFA) test. The model fit indices for the single factor CFA model conveyed a comparative fit index $(\mathrm{CFI})=$ 0.751, Tucker-Lewis index $(\mathrm{TLI})=0.710$, and root mean square error of approximation $($ RMSEA $)=0.128$. All CFA model fit indices were significantly worse than our measurement 
model (as shown in Appendix A). Based on these two tests, we can conclude that common method bias might not be a concern in our dataset (Sanchez \& Brock, 1996). Furthermore, Kull, Kotlar, and Spring (2018) argued that the effect of a single-key respondent in SMEs research is not very problematic since the small management structure can help to capture a broader picture of what is happening in SMEs.

\subsubsection{Confirmatory factor analysis.}

To investigate the unidimensionality, reliability, and validity of the theoretical constructs, we conducted a confirmatory factor analysis (CFA). One of the loadings within each of the study constructs was constrained to a value of one, and an estimation output using maximum likelihood was generated with standardised estimates, residual moments and modification indices. The hypothesised measurement model fit of data was satisfactory with values for model fit indices - normed $\mathrm{X}^{2}=1.99(\leq 2.0), \mathrm{p}<0.001, \mathrm{CFI}=0.934, \mathrm{TLI}=0.911 ;$ standardised root mean square residuals $(\mathrm{SRMR})=0.053$; and $\mathrm{RMSEA}=0.071$. We note that during the CFA process, we dropped one item each from supplier's asset specificity, supplier's complementary capabilities and OI scales to improve model fitting.

To establish discriminant validity, we compared the squared correlation between every two constructs in our model with their average variance extracted (AVE) values (Fornell \& Larcker, 1981). Examining the correlation coefficients given in Table 2 with the AVE values shown in Appendix A, we can conclude that none of the squared correlations is higher than the AVE of both the underlying constructs. The highest squared correlation of 0.403 between supplier's asset specificity and OI performance was lower than the AVE for the two constructs 0.48 and 0.50 , respectively. These results provide evidence of discriminant validity among proposed theoretical constructs. The descriptive statistics of the constructs and their correlations are shown in Table 2.

[Insert Table 2 about here] 
To evaluate the reliability of the study's constructs, we calculated the composite reliability (CR) for all constructs. Results showed that all constructs had a CR value of greater than or equal to 0.70 , confirming that items within each construct accounted for more variance than the variance explained by the error components; therefore, items are significantly related to their theoretical constructs (Bagozzi \& Yi, 2012). Reliability of the constructs was established using internal consistency method via Cronbach's alpha. All constructs showed Cronbach's alpha value of greater than 0.70. Also, the AVE values (Appendix A) are more than or equal to 0.5 for all constructs, except supplier's asset specificity and supplier's complementary capabilities, whose AVE value is 0.48. Adequate convergent validity is therefore exhibited (Fornell \& Larcker, 1981).

\section{Results}

\subsection{Hypotheses testing}

Since our hypothesised model (see Figure 1) involves mediation and moderation hypotheses with one mediator, one moderator, and two independent variables, we used models $4 \& 5$ illustrated in Preacher and Hayes (2008). Hayes's Process v3.0 tool tests mediation and moderation hypotheses using bootstrapping, a computer-intensive resampling from the data set for thousands of times (e.g. 5000) to build confidence interval of the empirical estimation of the mediation and interaction effects between variables (Lockwood \& MacKinnon, 1998). For our analysis, we used 5000 resampling iterations and a 95\% confidence interval for the approximation of the indirect effect.

Table 3 lists result from these tests. Table 3 also includes Sobel's test as a second test for mediation effects.

[Insert Table 3 about here] 
As shown in Table 3, the direct paths from supplier's asset specificity ( $b=0.403$, $t=7.020, p<0.001)$ and goal compatibility $(b=0.351, t=6.310, p<0.001)$ to the supplier's complementary capabilities, were positive and statistically significant. Also, the path from the supplier's complementary capabilities to OI performance $(b=0.192, t=2.536, p<0.01)$ is positive and statistically significant. These results support our hypothesis H1, H2 and H3. Furthermore, as shown in Table 3 the total effect of supplier's asset specificity $(b=0.555$, $t=8.977, p<0.001)$ and goal compatibility $(b=0.169, t=2.778, p<0.01)$ on OI performance is positive and significant. This result is consistent with the proposed mediation effect in our conceptual model (Preacher \& Hayes, 2008).

To study the mediation effects further, we compare the results shown in Table 3 between the total effects of supplier's asset specificity and goal compatibility on OI performance before and after we introduced supplier's complementary capabilities. The comparison shows that the effect of supplier's asset specificity on OI performance $(b=0.555$, $t=8.977, p<0.001)$ weakened $(b=0.478, t=7.004, p<0.001)$. Likewise, the effect of goal compatibility on OI performance became insignificant $(b=0.099, t=1.592, p=0.128)$. In summary, the results support the partial mediation of the supplier's asset specificity and full mediation of goal compatibility (H4a, H4b). Despite the robustness of Hayes's Process v3.0 tool approach in testing mediation hypotheses. We conducted Sobel test (Sobel, 1982, 1986) as a second approach to re-confirm the proposed mediation effect of supplier's complementary capabilities. Sobel's approach involves computing the ratio of the indirect effect to its estimated standard error. As shown in Table 3, Sobel test results support mediation of supplier's asset specificity $(z=2.352, p<0.05)$, and goal compatibility $(z=2.384, p<0.05)$, due to the introduction of supplier's complementary capabilities.

Contrary to our hypotheses $\mathrm{H} 5 \mathrm{a}$ and $\mathrm{H} 5 \mathrm{~b}$, our results do not provide support for the positive moderation effect of supplier rewarding joint action on the relationship between 
supplier's asset specificity and OI performance $(b=-0.053, t=-1.381, p=0.17)$ or between goal compatibility and OI performance $(b=-0.021, t=-0.687, p=.49)$. Instead, we found insignificant negative effects.

\section{Discussion}

Despite the broad scholarly consensus that supplier's complementarity in OI relationships is a determinant for collaboration and success, most of the empirical studies focused on studying the role of suppliers' complementarities in OI in the context of large firms. In this study, we extended the relational view (Dyer \& Singh, 1998) to the context of OI, and conducted a survey directly among SMEs. Our findings highlight the relevance of supplier's asset specificity and goal compatibility while assessing suppliers' complementarity in OI relationships. We empirically examined the performance effects of the antecedents and outcomes of supplier's complementary capabilities within the context of OI by SMEs. We affirmed that supplier's complementary capabilities are significantly related to OI performance. This finding, though consistent with the strategic-relational literature (Dyer \& Singh, 1998; Lavie, 2006), contradicts the TCE's traditions which postulate that firms will collaborate to acquire access to the supplier's complementary capabilities when the risks of collaboration are not too high (Nietoa \& Santamaria, 2007).

It is important to note that although the application and effectiveness of supplier's asset specificity and goal compatibility in fostering supplier's complementary capabilities are not limited to SMEs only, they are more in line with the SME entrepreneurs' interpersonal and relational competencies. Both are less expensive to measure, monitor and sufficient to incite the entrepreneurial mindset and the less risk averse behaviours of SMEs (Ferreira, Coelho, \& Moutinho, 2018; Julien, 1993). Consequently, our empirical evidence offers supplier's asset specificity and goal computability as essential relational mechanisms for SMEs to assess and 
leverage supplier's complementarity in achieving sustained collaborative advantages in OI relationships.

Our results confirm that SMEs might rely on supplier's asset specificity and goal compatibility to identify suppliers' strategic complementarity. Also, the supplier's asset specificity and goal compatibility can act as alternative mechanisms to long partnering experience and rigorous suppliers' search. This finding extends previous literature which predicted that supplier's specialised investments prove to be an effective tool in the cultivation of alliances' complementary capabilities (Mudambi \& Tallman, 2010). Such investments reflect the supplier's voluntary commitment to fulfil an SME's specific requirements from the OI relationhsip (Lavie, 2006; Sarkar et al., 2001). Additionally, while the supplier's asset specificity is instrumental in building the physical context of the supplier's complementary capabilities, goal compatibility weaves the social context of the supplier's complementary capabilities in OI relationships. Goal compatibility can reduce partners' fears of opportunism and compel them to focus on achieving relational outcomes (De Vita et al., 2010; Jean et al., 2017; Mudambi \& Tallman, 2010). Besides, goal compatibility increases the predictive power of interfirm complementarity in OI relationships not only due to its collaborative motivational dimension (Jap, 1999; Sarkar et al., 2001; Wang et al., 2016); but also due to its ability to blur firms' boundaries and galvanize innovation teams at both sides as one internal team.

It appears that under high supplier's asset specificity and high goal compatibility, SMEs can value and exploit the supplier's complementary capabilities in OI despite a significant risk of sensitive knowledge spill over and loss of competitive advantage (Aubert, Kishore, \& Iriyama, 2015; Gooroochurn \& Hanley, 2007; Hoecht \& Trott, 2006). Our empirical findings are in line with Lewin et al. (2009), who argue that access to qualified personnel, speed to market and cost savings are strong determinants of OI decisions. Moreover, our findings are also in keeping with Bertrand and Mol (2013), who concluded that benefits 
from accessing a broader range of innovation capabilities in OI outweighs looming risks, especially when compared with cost and risks of internal alternatives.

Our results show that the relationship between supplier's asset specificity with OI performance is partially explained through supplier's complementary capabilities. This finding suggests that the offshore supplier's contributions in the form of specific investments may exert a direct effect on OI performance. Also, supplier's specific investments - most likely to be specialised in case of OI in SMEs - foster building supplier's complementary capabilities, which in turn, affect OI performance (Enderwick \& Buckley, 2017). Therefore, both the direct and indirect effect of supplier's asset specificity confirm the competitive edge of differentiated supplier's investments in facilitating stronger performance in OI. Accordingly, supplier's asset specificity works on its own as well as through the development of supplier's complementary capabilities.

Findings from our research show that the relationship between goal compatibility and OI performance appears to occur mostly through supplier's complementary capabilities. This result extends the strategic-relational research which consistently finds that social similarities such as goal compatibility are fundamental elements in fostering successful collaborative relationships (Dyer \& Singh, 1998; Jap, 1999; Joshi \& Stump, 1999). For SME entrepreneurs, goal compatibility acts as an informal control mechanism for maintaining a collaborative climate that is conducive to superior OI performance (Bougrain \& Haudeville, 2002; Wang et al., 2016).

Interestingly, contrary to our hypotheses $\mathrm{H} 5 \mathrm{a}$ and $\mathrm{H} 5 \mathrm{~b}$, our results do not support the positive moderating effects of supplier joint actions. We advanced our propositions following theoretical underpinnings that a collaborative relationship with joint activities builds trust between partners by providing assurances of nonopportunistic behaviour, allowing them to focus on the mutual benefits of superior interfirm performance (Heide \& John, 1990; Joshi \& 
Stump, 1999). Moreover, through supplier joint actions, suppliers receive financial benefits as an economic return on their specific investments and the unique adaptations they have made to their internal processes (Krause \& Scannell, 2002; Modi \& Mabert, 2007; Munjal et al., 2018). Furthermore, as a result of supplier joint actions, suppliers perceive buyer firms as "fair" partners concerned with the suppliers' goals and welfare (Liu et al., 2012). However, our results did not find the support of these relationships.

Some of the possible rationalisations for these contradictory finding is: First, despite supplier's potential gains from joint actions, they do not qualify as equal hostages that balance supplier's risks from dedicated and difficult to re-deploy specific assets. For example, Anderson and Jap (2005) argued that only mutual specialised and unrecoverable investments could ensure that both partners have the same high stakes in the relationship. Second, supplier joint actions have no value for an invested supplier once the buyer decides to end the relationship. Third, suppliers' valuation of incentives accrued from joint actions is more important than the incentives themselves (Gilliland \& Kim, 2014). Therefore, for any incentive to motivate OI performance, it needs to be high enough to win the supplier's compliance and commitment in OI relationships (Gilliland \& Kim, 2014). Fourth, as incentives, supplier joint actions can also be context dependent, hence their power and effectiveness is rather hinged on the scope of interfirm cooperation and the odds of continuation or termination of the OI relationship (Gilliland \& Kim, 2014; Kim et al., 2015; Stump \& Heide, 1996).

\section{Conclusions and Implications}

OI differs from typical offshore outsourcing not only when it comes to motives and characteristics, but also in the extensive level of dyadic interactions required, which in turn affects the outcomes of OI relationships. These differences clearly highlight that the outcome of OI depends on how SMEs choose to access and leverage the offshore supplier's complementary capabilities. The empirical investigation we carried out in this study provides 
further evidence that the offshore supplier's contributions and partners' goal compatibility are contingencies under which supplier's complementary capabilities could improve OI performance. SMEs who apply the supplier's asset specificity and goal compatibility can gain more relational rents from OI relationships. Our results confirm that the effect of the supplier's complementarity on OI performance is further explained by the specialised capabilities brought by the supplier to the collaboration framework. Also, the positive association of goal compatibility with the OI performance appeared to occur largely through dyadic complementarity.

Our research exposes the downside of SMEs limited resources which undermines their abilities to search and select champion offshore suppliers. However, SME managers may apply supplier's asset specificity and goal compatibility as affordable ways to accrue relational rents in their OI relationships. Our framework provides SMEs' managers with a basis for more effective management of collaborative OI dyads. For example, selecting offshore suppliers who are willing to invest and adapt to meet the SMEs' goals from OI is highly relevant to achieve supplier's complementarity. Also, OI collaborations can benefit greatly from goal compatibility in encouraging the offshore supplier to pursue collective gains.

The results of this study call for a deeper understanding of the nature and effect of supplier joint actions in OI relationships, especially in case of suppliers with high specific investment stakes. In other words, high supplier's asset specificity may downplay the incentivising power of supplier joint actions. Our findings prompt SMEs managers to think carefully about incentivising offshore suppliers' collaboration behaviour via supplier joint actions. For example, SMEs must determine what type of supplier joint actions might encourage the offshore supplier to collaborate more and subsequently use the appropriate level of these actions to drive super relational rents from the OI relationship. Therefore, SME 
managers should grasp that although supplier joint actions can be effective cooperation tools, they may always not work.

\subsection{Limitations and future research}

The present study has several limitations that would provide avenues for future research. First, we sampled our SMEs from the developed country manufacturers in Germany, Italy, UK, and France. It would be interesting to see if our findings are generalizable to different industries and geographies including services and SMEs in developing countries. Second, despite the verified reliability of our findings, it is noteworthy that we relied on the SME's perspectives and qualifications as a proxy for evaluating dyadic constructs. A direct investigation of the offshore suppliers' perspectives could have enabled us to draw different conclusions (e.g. the non-supported moderating effect of supplier joint actions). Also, extending suppliers joint activities to include other incentives such as profit sharing or. assigning intellectual property rights of collective innovations might have revealed stronger effects of these incentives on OI performance. Third, drawing upon the less experienced than large firms position of SMEs in OI dyads, an exciting prospect of future research will be to define the minimum resources and operational attributes that an offshore supplier must own to qualify as a robust collaborator for OI. Other good prospects for future research would be to compare the unique benefits of offshoring innovation with in-country outsourcing innovation. For example, will countryspecific factors such as linguistic or cultural similarities make collaboration easier between countries in the context of OI? Also, an interesting avenue for future research would be to investigate whether SMEs should refrain from using OI given the difficulties surrounding the control and coordination of such innovation sourcing strategies, let alone the possibility of realising harmful consequences of OI in case of suppliers' free-riding behaviour. Despite these limitations and generalisability precautions of OI in SMEs, we believe that this study 
Offshoring Innovation in SMEs

contributes to the OI management literature in SMEs and enhances our understanding of how SMEs and large firms are different. 


\section{References}

Albors-Garrigos, J., Etxebarria, N. Z., Hervas-Oliver, J. L., \& Epelde, J. G. (2011). Outsourced innovation in SMES: a field study of R\&D units in Spain. International Journal of Technology Management, 55(1-2), 138-155. doi:10.1504/ijtm.2011.041684

Ambos, B., \& Ambos, T. C. (2011). Meeting the challenge of offshoring R\&D: an examination of firmand location-specific factors. $R \& D$ Management, $41(2), 107-119$. doi:https://doi.org/10.1111/i.1467-9310.2010.00625.x

Anderson, E., \& Jap, S. D. (2005). The dark side of close relationships. Mit Sloan Management Review, 46(3), 75-82.

Aubert, B. A., Kishore, R., \& Iriyama, A. (2015). Exploring and managing the "innovation through outsourcing" paradox. Journal of Strategic Information Systems, 24(4), 255-269. doi:10.1016/j.jsis.2015.10.003

Bagozzi, R. P., \& Yi, Y. (2012). Specification, evaluation, and interpretation of structural equation models. Journal of the Academy of Marketing Science, 40(1), 8-34.

Bertrand, O., \& Mol, M. J. (2013). The antecedents and innovation effects of domestic and offshore R\&D outsourcing: The contingent impact of cognitive distance and absorptive capacity. Strategic Management Journal, 34(6), 751-760. doi:10.1002/smj.2034

Bidault, F., \& Castello, A. (2010). Why too much trust is death to innovation. Mit Sloan Management Review, 51(4), 33-38.

Bougrain, F., \& Haudeville, B. (2002). Innovation, collaboration and SMEs internal research capacities. Research Policy, 31(5), 735-747.

Bunyaratavej, K., Hahn, E. D., \& Doh, J. P. (2007). International offshoring of services: A parity study. Journal of International Management, 13(1), 7-21. doi:https://doi.org/10.1016/i.intman.2006.05.002

Buvik, A., \& John, G. (2000). When does vertical coordination improve industrial purchasing relationships? Journal of Marketing, 64(4), 52-64. doi:https://doi.org/10.1509/jmkg.64.4.52.18075

Carr, A. S., \& Pearson, J. N. (1999). Strategically managed buyer-supplier relationships and performance outcomes. Journal of Operations Management, 17(5), 497-519. doi:https://doi.org/10.1016/S0272-6963(99)00007-8

Chen, I. J., \& Paulraj, A. (2004). Towards a theory of supply chain management: the constructs and measurements. Journal of Operations Management, 22(2), 119-150.

Chen, L. H., Ellis, S. C., \& Suresh, N. (2016). A supplier development adoption framework using expectancy theory. International Journal of Operations \& Production Management, 36(5), 592-615. doi:https://doi.org/10.1108/IJOPM-09-2013-0413

Chiang, C. Y., Kocabasoglu-Hillmer, C., \& Suresh, N. (2012). An empirical investigation of the impact of strategic sourcing and flexibility on firm's supply chain agility. International Journal of Operations \& Production Management, 32(1), 49-78. doi:https://doi.org/10.1108/01443571211195736

Cobena, M., Gallego, A., \& Casanueva, C. (2017). Heterogeneity, diversity and complementarity in alliance portfolios. European Management Journal, 35(4), 464-476. doi:10.1016/j.emj.2016.12.005

De Vita, G., Tekaya, A., \& Wang, C. L. (2010). Asset specificity's impact on outsourcing relationship performance: A disaggregated analysis by buyer-supplier asset specificity dimensions. Journal of Business Research, 63(7), 657-666. doi:10.1016/j.jbusres.2009.04.019

Di Gregorio, D., Musteen, M., \& Thomas, D. E. (2009). Offshore outsourcing as a source of international competitiveness for SMEs. Journal of International Business Studies, 40(6), 969988. doi:10.1057/jibs.2008.90 
Dussauge, P., Garrette, B., \& Mitchell, W. (2000). Learning from competing partners: outcomes and durations of scale and link alliances in Europe, North America and Asia. Strategic Management Journal, 21(2), 99-126.

Dyer, J. H. (1996). Specialized supplier networks as a source of competitive advantage: Evidence from the auto industry. Strategic Management Journal, 17(4), 271-291.

Dyer, J. H., \& Singh, H. (1998). The relational view: Cooperative strategy and sources of the interorganizational competitive advantage. Academy of Management Review, 23(4), 660697. Retrieved from http://www.jstor.org/stable/pdf/259056.pdf

Enderwick, P., \& Buckley, P. J. (2017). Beyond supply and assembly relations: Collaborative innovation in global factory systems. Journal of Business Research, In press, 1-10. doi:https://doi.org/10.1016/i.jbusres.2017.09.004

European Commission. (2016). Annual Report on European SMEs 2015 / 2016: SME recovery continues. Retrieved from Luxembourg:

Eurostat. (2016). Eurostart yearbook Retrieved from http://ec.europa.eu/eurostat/statisticsexplained/index.php?title=India-

EU \%E2\%80\%93 international trade in goods statistics\&oldid=355530\#EU and India in world trade in goodsS

Eurostat. (2017). Eurostat yearbook.

Fernández-Olmos, M., \& Ramírez-Alesón, M. (2017). How internal and external factors influence the dynamics of SME technology collaboration networks over time. Technovation, 64-65(1), 1627. doi:https://doi.org/10.1016/j.technovation.2017.06.002

Ferreira, J., Coelho, A., \& Moutinho, L. (2018). Dynamic capabilities, creativity and innovation capability and their impact on competitive advantage and firm performance: The moderating role of entrepreneurial orientation. Technovation, Available online 12 December 2018, 1-18. doi:http://doi.org/10.1016/i.technovation.2018.11.004

Flynn, B. B., Hou, B., \& Zhao, X. (2010). The impact of supply chain integration on performance: A contingency and configuration approach. Journal of Operations Management, 28(1), 58-71. doi:10.1016/j.jom.2009.06.001

Fornell, C., \& Larcker, D. F. (1981). Structural equation models with unobservable variables and measurement error: Algebra and statistics. Journal of Marketing Research, 18(3), 382-388.

Forsgren, M. (2002). The concept of learning in the Uppsala internationalization process model: a critical review. International Business Review, 11(3), 257-277.

Frishammar, J., Ericsson, K., \& Patel, P. C. (2015). The dark side of knowledge transfer: Exploring knowledge leakage in joint R\&D projects. Technovation, 41-42(1), 75-88. doi:https://doi.org/10.1016/j.technovation.2015.01.001

Gassmann, O., Enkel, E., \& Chesbrough, H. (2010). The future of open innovation. R\&D Management, 40(3), 213-221. doi:10.1111/j.1467-9310.2010.00605.x

Geishecker, I., \& Görg, H. (2013). Services offshoring and wages: evidence from micro data. Oxford Economic Papers, 65(1). doi:https://www.jstor.org/stable/23463414

Gilliland, D. I., \& Kim, S. K. (2014). When do incentives work in channels of distribution? Journal of the Academy of Marketing Science, 42(4), 361-379. doi:https://doi.org/10.1007/s11747-013$\underline{0364-3}$

Gooroochurn, N., \& Hanley, A. (2007). A tale of two literatures: Transaction costs and property rights in innovation outsourcing. Research Policy, 36(10), 1483-1495. doi:10.1016/j.respol.2007.07.001

Gulati, R., Lavie, D., \& Singh, H. (2009). THE NATURE OF PARTNERING EXPERIENCE AND THE GAINS FROM ALLIANCES. Strategic Management Journal, 30(11), 1213-1233. doi:10.1002/smj.786

Gusenbauer, M., Massini, S., \& Fink, M. (2015). Innovation offshoring by small and medium-sized enterprises - Establishing the research gap. In I. Oshri, J. Kotlarsky, \& L. P. Willcocks (Eds.), Achieving Success and Innovation in Global Sourcing: Perspectives and Practices (Vol. 236, pp. 156-170). 
Hagedoorn, J. (2002). Inter-firm R\&D partnerships: an overview of major trends and patterns since 1960. Research Policy, 31(4), 477-492.

Hamel, G., Doz, Y. L., \& Prahalad, C. K. (1989). Collaborate with your competitors to win. Harvard Business Review, 67(1), 133-139.

Heide, J. B., \& John, G. (1990). Alliances in Industrial Purchasing: The Determinants of Joint Action in Buyer-SupplierRelationships. Journal of Marketing Research, 27(1), 24-36.

Hoecht, A., \& Trott, P. (2006). Innovation risks of strategic outsourcing. Technovation, 26(5-6), 672681. doi:10.1016/j.technovation.2005.02.004

Huq, F. A., Stevenson, M., \& Zorzini, M. (2014). Social sustainability in developing country suppliers: An exploratory study in the ready made garments industry of Bangladesh. International Journal of Operations \& Production Management, 34(5), 610-638. doi:10.1108/IJOPM-102012-0467

Jane, R. J., Kim, D., \& Sinkovics, R. R. (2012). Drivers and performance outcomesof supplier innovation generationin customer-supplier relationships:The role of power-dependence. Decision Sciences, 43(6), 1003-1038.

Jap, S. D. (1999). Pie-Expansion Efforts: Collaboration Processes in Buyer-Supplier Relationships. Journal of Marketing Research, 36(4), 461-475.

Jean, R. J., Kim, D., \& Bello, D. C. (2017). Relationship-based product innovations: Evidence from the global supply chain. Journal of Business Research, 80, 127-140. doi:https://doi.org/10.1016/i.jbusres.2017.07.008

Jean, R. J., Sinkovics, R. R., \& Hiebaum, T. P. (2014). The effects of supplier involvement and knowledge protection on product innovation in customer-supplier relationships: A study of global automotive suppliers in China. The Journal of Product Innovation Management, 3(1), 98-113. doi:DOI: 10.1111/jpim.12082

Johnson, H. A. W., \& Medcof, J. W. (2007). Motivating proactive subsidiary innovation: Agent-based theory and socialization models in global R\&D. Journal of International Management, 13(4), 472-487.

Joshi, A. W., \& Stump, R. L. (1999). The Contingent Effect of Specific Asset Investments on Joint Action in Manufacturer-Supplier Relationships: An Empirical Test of the Moderating Role of Reciprocal Asset Investments, Uncertainty, and Trust. Journal of the Academy of Marketing Science, 27(3), 291-305.

Julien, P. A. (1993). Small businesses as a research subject: some reflections on knowledge of small businesses and its effects on economic theory. Small Business Economics, 5(2), 157-166.

Kim, Y., Choi, T. Y., \& Skilton, P. F. (2015). Buyer-supplier embeddedness and patterns of innovation. International Journal of Operations \& Production Management, 35(3), 318-345. doi:https://doi.org/10.1108/IJOPM-05-2013-0251

Koufteros, X., Vickery, S. K., \& Dorge, C. (2012). The Effects of strategic supplier selection on buyer competitive performance in matched domains: Does supplier integration mediate the relationships? Journal of Supply Chain Management, 48(2), 83-115. doi:10.1111/j.1745493X.2012.03263.x

Krause, D. R., \& Scannell, T. V. (2002). Supplier Development Practices: Product- and Service-Based Industry Comparisons. Journal of Supply Chain Management, 38(1), 13-21. doi:https://doi.org/10.1111/i.1745-493X.2002.tb00125.x

Kulangara, N. P., Jackson, S. A., \& Prater, E. (2016). Examining the impact of socialization and information sharing and the mediating effect of trust on innovation capability. International Journal of Operations \& Production Management, 36(11), 1601-1624. doi:10.1108/ijopm-092015-0558

Kull, T. J., Kotlar, J., \& Spring, M. (2018). Small and medium enterprise research in supply chain management: The case for single-respondent research designs. Journal of Supply Chain Management, 54(1), 23-34. 
Laforet, S. (2008). Size, strategic, and market orientation affects on innovation. Journal of Business Rsearch, 61(7), 753-769.

Lavie, D. (2006). The competitive advantage of interconnected firms: an extension of the resourcebased view. Academy of Management Review, 31(3), 638-658.

Lawson, B., Krause, D., \& Potter, A. (2015). Improving Supplier New Product Development Performance:The Role of Supplier Development. The Journal of Product Innovation Management, 32(5), 777-792. doi:10.1111/jpim.12231

Lee, S., Park, G., Yoon, B., \& Park, J. (2010). Open innovation in SMEs-An intermediated network model. Research Policy, 39(2), 290-300. doi:10.1016/j.respol.2009.12.009

Lewin, A. Y., Massani, S., \& Peeters, C. (2009). Why are companies offshore outsourcing innovation? The emerging global race for talent. Journal of International Business Studies, 40(6), 901-925. doi:10.1057/jibs.2008.92

Liu, Y., Huang, Y., Luo, Y., \& Zhao, Y. (2012). How does justice matter in achieving buyer-supplier relationship performance. Journal of Operations Management, 30(5), 355-367.

Lockwood, C. M., \& MacKinnon, D. P. (1998). Bootstrapping the standard error of the mediated effect. Paper presented at the Proceedings of the 23rd Annual Meeting of SAS Users Group Internationa, Cary, NC.

Lui, C. L., Ghauri, P. N., \& Sinkovics, R. R. (2010). Understanding the impact of relational capital and organizational learning on alliance outcomes. Journal of World Business, 45(3), 237-249.

Marcati, A., Guidoa, G., \& Peluso, A. M. (2008). The role of SME entrepreneurs' innovativeness and personality in the adoption of innovations. Research Policy, 37(9), 1579-1590.

Maskell, P., Pedersen, T., Petersen, B., \& Dick-Nielsen, J. (2007). Learning paths to offshore outsourcing: From cost Reduction to knowledge seeking. Industry and Innovation, 14(Industry and Innovation3), 239-257. doi:https://doi.org/10.1080/13662710701369189

Mindruta, D., Moeen, M., \& Agarwal, R. (2016). A two-sided matching approach for partner selection and assessing complementarities in partners' attributes in inter-firm alliances. Strategic Management Journal, 37(1), 206-231.

Mitsuhashi, H., \& Greve, H. R. (2009). A matching theory of alliance formation and organizational success: complementarity. The Academy of Management Journal, 52(5), 975-995.

Modi , S. B., \& Mabert, V. A. (2007). Supplier development: Improving supplier performance through knowledge transfer. Journal of Operations Management, 25(1), 42-64. doi:https://doi.org/10.1016/j.jom.2006.02.001

Mooi, E. A., \& Ghosh, M. (2010). Contract Specificity and Its Performance Implications. Journal of Marketing, 74 (2), 105-120.

Mudambi, S. M., \& Tallman, S. (2010). Make, buy or ally? Theoretical perspectives on knowledge process outsourcing through alliances. Journal of Management Studies, 47(8), 1434-1456.

Munjal, S., Requejo, I., \& Kundu, S. K. (2018). Offshore outsourcing and firm performance: Moderating effects of size, growth and slack resources. Journal of Business Research, In Press, 1-11. doi:https://doi.org/10.1016/i.jbusres.2018.01.014

Musteen, M., \& Ahsan, M. (2013). Beyond cost: The role of intellectual capital in offshoring and innovation in young firms. Entrepreneurship Theory and Practice, 37(2), 421-434. doi:10.1111/j.1540-6520.2011.00477.x

Mykhaylenko, A., Motika, A., Waehrens, B. V., \& Slepniov, D. (2015). Accessing offshoring advantages: what and how to offshore. Strategic Outsourcing: An International Journal, 8(23), 262-283. doi:10.1108/SO-07-2015-0017

Nietoa, M. J., \& Santamaria, L. (2007). The importance of diverse collaborative networks for the novelty of product innovation. Technovation, 27(6-7), 367-377.

Nyaga, G. N., Whipple, J. M., \& Lynch, D. F. (2010). Examining supply chain relationships: Do buyer and supplier perspectives on collaborative relationships differ? Journal of Operations Management, 28(2), 101-114. 
Palmie, M., Zeschky, M., Winterhalter, S., Sauter, P. W., Haefner, N., \& Gassmann, O. (2016). Coordination mechanisms for international innovation in SMEs: effects on time-to-market and R\&D task complexity as a moderator. Small Business Economics, 46(2), 273-294. doi:10.1007/s11187-015-9683-8

Paulraj, A., Lado, A. A., \& Chen, I. J. (2008). Inter-organizational communication as a relational competency: Antecedents and performance outcomes in collaborative buyer-supplier relationships. Journal of Operations Management, 26(1), 45-64.

Pawar, K., Huq, F. A., Khraishi, A., \& Shah, J. (2018). Contextualisation of the complexity in the selection of developing country outsourcees by developed country outsourcers. International Journal of Production Research. doi:https://doi.org/10.1080/00207543.2018.1529444

Podsakoff, P. M., MacKenzie, S. B., Lee, J. Y., \& Podsakoff, N. P. (2003). Common Method Biases in Behavioral Research: A Critical Review of the Literature and Recommended Remedies. Journal of Applied Psychology, 88(5), 879-903.

Poole, M. S., \& Van de Ven, A. H. (1995). Explaining Development and Change in Organizations. The Academy of Management Review, 20(3), 510-540.

Poppo, L., Zhou, K. Z., \& Zenger, T. R. (2008). Examining the conditional limits of relational governance: specialized Assets, performance ambiguity, and long-standing ties. Journal of Management Studies, 45(7), 1195-1216. doi:https://doi.org/10.1111/i.14676486.2008.00779.x

Preacher, K., \& Hayes, A. (2008). Asymptotic and resampling strategies for assessing and comparing indirect effects in multiple mediator models. Behavior Research Methods, 40(3), 879-891.

Quinn, J. B. (2000). Outsourcing innovation. MIT SloanManagement Review, 41(1), 13-28.

Quinn, J. B., \& Hilmer, F. G. (1994). Strategic Outsourcing. Sloan Management Review, 35(4), 43-55.

Rindfleisch, A., \& Moorman, C. (2001). The acquisition and utilization of information in new product alliances: A strength-of ties perspective. Journal of Marketing, 65(1), 1-18.

Rodriguez, A., \& Nieto, M. J. (2016). Does offshoring R\&D lead to SME growth? Different governance modes and the mediating role of innovation Strategic Management Journal, 37(8), 17341753.

Rothaermel, F. T., \& Boeker, W. (2008). Old technology meets new technology: complementarities, similarities, and alliance formation. Strategic Management Journal, 29(1), 47-77.

Rothwell, R., \& Dodgson, M. (1991). External linkages and innovation in small and medium-sized enterprises. $R$ \& D Management, 21(2), 125-137.

Roy, S., \& Sivakumar, K. (2011). Managing intellectual property in global outsourcing for innovation generation. Journal of Product Innovation Management, 28(1), 48-62. doi:10.1111/j.15405885.2010.00780.x

Sanchez, J. I., \& Brock, P. (1996). Outcomes of Perceived Discrimination among Hispanic Employees: Is Diversity Management a Luxury or a Necessity? The Academy of Management Journal, 39(3), 704-719.

Sarkar, M., Echambadi, R., Cavusgil, T. S., \& Aulakh, P. S. (2001). The Influence of Complementarity, Compatibility, and Relationship Capital on Alliance Performance. Journal of the Academy of Marketing Science, 29(4), 358-373.

Sartor, M. A., \& Beamish, P. W. (2014). Offshoring innovation to emerging markets: Organizational control and informal institutional distance. Journal of International Business Studies, 45(9), 1072-1095. doi:10.1057/jibs.2014.36

Shepherd, D. A., \& DeTienne, D. R. (2005). Prior knowledge, potential financial reward, and opportunity identification. Entrepreneurship Theory and Practice, 29(1), 91-112.

Sivadas, E., \& Dwyer, R. (2000). An examination of organizational factors influencing new product success in internal and alliance-based processes. Journal of Marketing, 64(1), 31-49.

Sobel, M. E. (1982). Asymptotic confidence intervals for indirect effects in structural equation models. Sociological Methodology, 13(1), 290-312. 
Sobel, M. E. (1986). Some new results on indirect effects and their standard errors in covariance structure models. Sociological Methodology, 16(1), 159-186.

Spithoven, A., \& Teirlinck, P. (2015). Internal capabilities, network resources and appropriation mechanisms as determinants of R\&D outsourcing. Research Policy, 44(3), 711-725. doi:10.1016/j.respol.2014.10.013

Stanko, M. A., \& Calantone, R. J. (2011). Controversy in innovation outsourcing research: review, synthesis and future directions. $R$ \& D Management, 41(1), 8-20. doi:10.1111/j.14679310.2010.00624.x

Stump, R. L., \& Heide, J. B. (1996). Controlling supplier opportunism in industrial relationships. Journal of Marketing Research, 33(4), 431-444. doi:https://doi.org/10.1177/002224379603300405

Sumo, R., van der Valk, W., van Weele, A., \& Bode, C. (2016). Fostering incremental and radical innovation through performance-based contracting in buyer-supplier relationships. International Journal of Operations \& Production Management, 36(11), 1482-1503. doi:10.1108/ijopm-05-2015-0305

Teece, D. J. (1986). Profiting from technological innovation: Implications for integration, collaboration, licensing and public policy. Research Policy, 15(6), 285-305.

Van Beers, C., \& Zand, F. (2014). R\&D cooperation, partner diversity, and innovation performance: An empirical analysis. Journal of Product Innovation Management, 31(2), 292-312.

van de Vrande, V., de Jong, J. P. J., Vanhaverbeke, W., \& de Rochemont, M. (2009). Open innovation in SMEs: Trends, motives and management challenges. Technovation, 29(6-7), 423-437.

Villenaa, V. H., Revillaa, E., \& Thomas Y. Choi, T. Y. (2011). The dark side of buyer-supplier relationships: A social capital perspective. Journal of Operations Management, 29(6), 561576.

von Haartman, R., \& Bengtsson, L. (2015). The impact of global purchasing and supplier integration on product innovation. International Journal of Operations \& Production Management, 35(9), 1295-1311. doi:https://doi.org/10.1108/IJOPM-03-2015-0128

Wang, J. J., Li, J. J., \& Chang, J. (2016). Product co-development in an emerging market: The role of buyer-supplier compatibility and institutional environment. Journal of Operations Management, 46(1), 69-83.

Werder, K. P. (2005). An empirical analysis of the influence of perceived attributes of publics on public relations strategy use and effectiveness. Journal of Public Relations Research, 17(3), 217-266.

Whitley, E. A., \& Willcocks, L. (2011). ACHIEVING STEP-CHANGE IN OUTSOURCING MATURITY: TOWARD COLLABORATIVE INNOVATION. Mis Quarterly Executive, 10(3), 95-107. Retrieved from $<$ Go to $|S|>: / /$ WOS:000294818000001

Zhang, X., Dirk Pieter Van Donk, D. P., \& van der Vaart, T. (2016). The different impact of interorganizational and intra-organizational ICT on supply chain performance. International Journal of Operations \& Production Management, 36(7), 803-824. doi:https://doi.org/10.1108/IJOPM-11-2014-0516 
Table 1. SMEs Sample Characteristics

\begin{tabular}{lcc}
\hline Industry & Frequency & $\%$ \\
\hline Plastic, paper, and rubber & 32 & $16.0 \%$ \\
Textile and wearing apparel & 32 & $16.0 \%$ \\
Food and beverages & 23 & $11.5 \%$ \\
Machinery and mechanical equipment & 24 & $12.0 \%$ \\
Pharmaceutical and chemicals & 20 & $10.0 \%$ \\
Wood and furniture & 20 & $10.0 \%$ \\
Metal and minerals & 18 & $9.0 \%$ \\
Electrical and electronics & 16 & $8.0 \%$ \\
Coke and petroleum & 10 & $5.0 \%$ \\
Other manufacturing & 5 & $2.5 \%$ \\
\hline Title of respondents & Frequency & $\%$ \\
\hline Chief executive officer & 8 & $4.0 \%$ \\
Managing director & 69 & $34.5 \%$ \\
Managing partner & 94 & $47.0 \%$ \\
General manager & 25 & $12.5 \%$ \\
Others (top management position) & 4 & $2.0 \%$ \\
\hline
\end{tabular}

Table 2 Descriptive statistics and correlations

\begin{tabular}{lccccc}
\hline Construct & 1. & 2. & 3. & 4. & 5. \\
\hline 1. Supplier's asset specificity & 1.000 & & & & \\
2. Goal compatibility & $0.480^{\star *}$ & 1.000 & & & \\
3. Supplier's complementary capabilities & $0.597^{\star *}$ & $0.575^{* *}$ & 1.000 & & \\
4. Supplier joint actions & $0.433^{\star *}$ & $0.461^{* *}$ & $0.408^{\star *}$ & 1.000 & \\
5. Offshoring innovation & $0.635^{\star *}$ & $0.436^{\star *}$ & $0.527^{\star *}$ & $0.316^{\star *}$ & 1.000 \\
& & & & & \\
Mean & 5.528 & 5.613 & 5.613 & 5.527 & 5.598 \\
Standard deviation & 0.656 & 0.675 & 0.630 & 0.816 & 0.658 \\
\hline
\end{tabular}


Table 3. Results of direct, mediation and moderation effects

Direct effect

Moderation

Moderation (Goal

(Supplier's Asset

Specificity $\mathrm{x}$

Supplier Joint

Actions)

Supplier Joint Actions)

\section{Hypothesis}

(H1, H2)

(H3, H4a, H4b)

(H5a)

(H5b)

Effect / Unstandardized Coefficients

$b(t)$

$b(t)$

$b(t)$

$b(t)$

$b(t)$

Supplier's asset specificity $\rightarrow$ supplier's complementary capabilities

Goal compatibility $\rightarrow$ supplier's complementary capabilities

Supplier's asset specificity $\rightarrow$ offshoring

innovation

Goal compatibility $\rightarrow$ offshoring innovation

Supplier's complementary capabilities $\rightarrow$ offshoring innovation

Supplier joint actions x Supplier's asset specificity

Supplier joint actions x Goal compatibility

Indirect effect (supplier's asset specificity)

95\% Confidence interval (supplier's asset

specificity)

Sobel test (supplier's asset specificity)

Indirect effect (goal compatibility)

95\% Confidence interval (goal compatibility)

Sobel test (goal compatibility)

Degrees of freedom (d.f.)

Variance Explained $\left(\mathrm{R}^{2}\right)$

F-stats

$\mathrm{t}$ and F-values significance levels: $* \mathrm{p}<0.05, * * \mathrm{p}<0.01, * * * \mathrm{p}<0.00$
$0.403 * * *(7.020)$

$0.351 * * *(6.310)$

$\begin{array}{cccc}0.555 * * *(8.977) & 0.478 * * *(7.004) & 0.455 * * *(6.283) & 0.474 * * *(6.678) \\ 0.169 * *(2.778) & 0.099(1.529) & 0.061(0.828) & 0.075(0.934) \\ & 0.192 * *(2.536) & 0.194 *(2.551) & 0.191 *(2.500) \\ & & -0.053(-1.381) & \end{array}$

0.077

$0.005-0.163$

$2.352 *$

0.068

$0.006-0.133$

$2.384^{*}$

$\begin{array}{ccccc}197 & 197 & 196 & 194 & 194 \\ 0.465^{* * *} & 0.425^{* * *} & 0.444^{* * *} & 0.449^{* * * *} & 0.445^{* * *} \\ 85.488 & 72.911 & 52.091 & 31.649 & 31.133\end{array}$


Offshoring Innovation in SMEs 
Figure 1. Proposed model of supplier's complementary capabilities of the offshore outsourcing innovation dyad

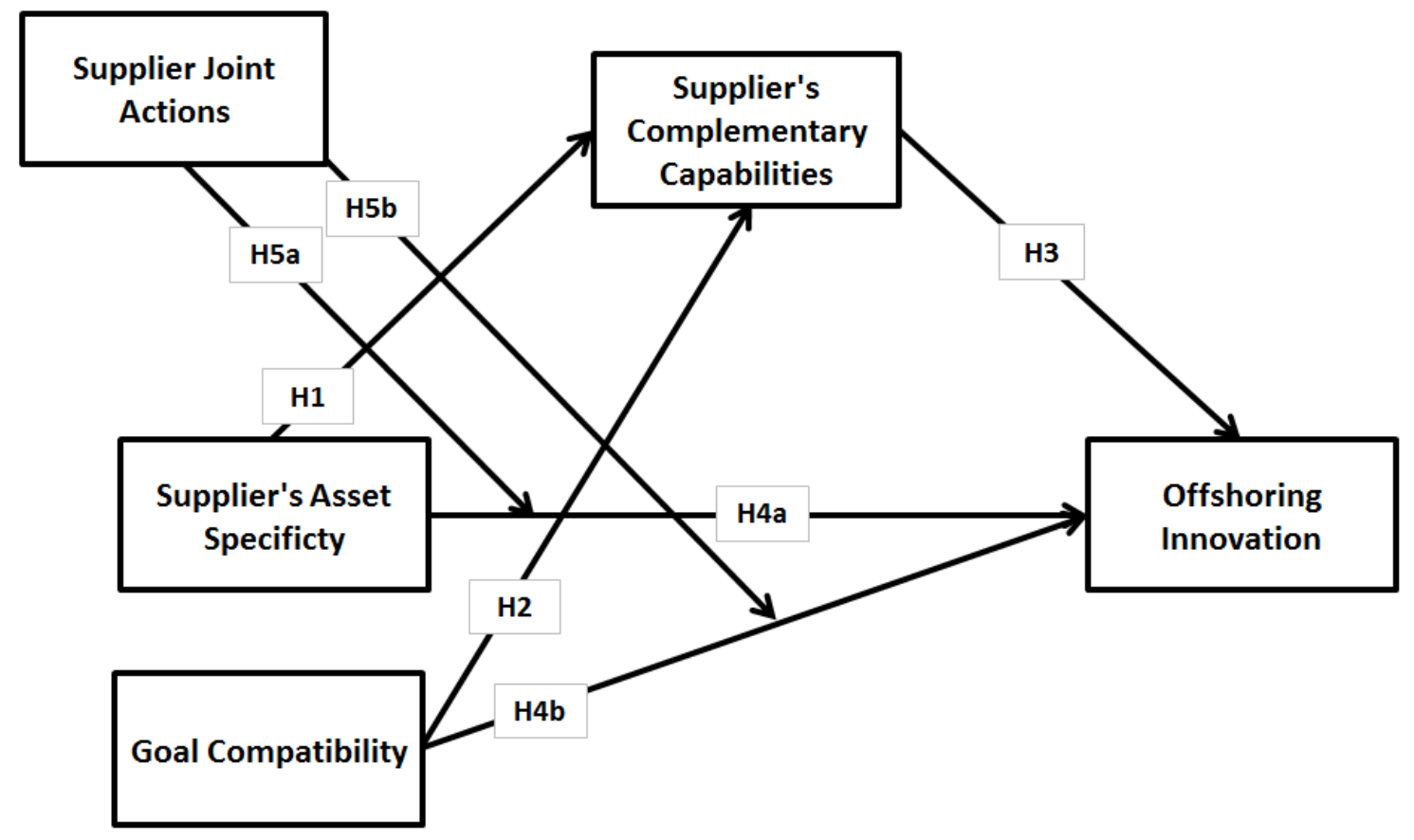




\section{Appendix A}

Construct (Cronbach's alpha, composite reliability (CR), average variance extracted

AMOS item (AVE))

Supplier's Asset Specificity $(\alpha=0.71 ; \mathrm{CR}=0.73 ; \mathrm{AVE}=0.48)$

a) Our innovation requirements need highly specified human and physical resources

0.62

b) The offshore supplier has made significant investment in specialized human and physical resources dedicated to our relationship

c) The offshore supplier has tailored its product and process development programs to match our requirements.

d) The offshore supplier has committed specialized skills in training our people*

Goal Compatibility $(\alpha=0.71 ; C R=0.78 ; \mathrm{AVE}=0.55)$

a) Our firm and the offshore supplier have compatible goals

b) Our firm and the offshore supplier support each other's objectives

c) Our firm and the offshore supplier share the same goals in the relationship

Supplier's Complementary Capabilities $(\alpha=0.74 ; \mathrm{CR}=0.70 ; \mathrm{AVE}=0.48)$

a) The offshore supplier contributes different capabilities to our relationship

b) The offshore supplier has complementary strengths that are useful to our relationship*

c) The offshore supplier has separate abilities that, when combined with our abilities enable us to achieve goals beyond our reach independently

d) The R\&D efforts benefit from their closeness to both firms' current products and processes

Supplier joint actions $(\alpha=0.74 ; C R=0.76 ; A V E=0.53)$

a) We work jointly with the offshore supplier to reduce its costs

b) We work jointly with the offshore supplier to improve its quality

c) We work jointly with the offshore supplier on training its people

0.64

Offshoring innovation $(\alpha=0.73 ; \mathrm{CR}=0.74 ; \mathrm{AVE}=0.50)$

a) As result of our relationship with the offshore supplier, we have created new products and/or enhanced our current products.

b) As a result of our relationship with the offshore supplier, we have created new processes and/or improved our current processes.

c) As a result of our relationship with the offshore supplier, we have Increased our new product speed to market. *

d) As a result of our relationship with the offshore supplier, we have Increased our patent application rate.

Model fit indices: Normed $\mathrm{X}^{2}=1.99(\leq 2.0), \mathrm{p}<0.001$, comparative fit index $(\mathrm{CFI})=$ 0.934, Tucker-Lewis index $(\mathrm{TLI})=0.911$, standardised root mean square residuals $(\mathrm{SRMR})=0.053$, and root mean square error of approximation $($ RMSEA $)=0.071$. Note*Item dropped after CFA 